\title{
Sexual orientation and wage differentials using anthropometric and health measures
}

\author{
Daniel Suliano ${ }^{1}$ \\ Jaime de Jesus Filho \\ Guilherme Irffi $^{3}$
}

\begin{abstract}
This paper analyzes salary differentials based on sexual orientation. Hitherto, the incipient studies addressing the theme in Brazil used the 2010 demographic census conducted by the Brazilian Institute of Geography and Statistics (IBGE). However, the implementation of the Integrated Household Survey System (SIPD) in IBGE's sample surveys started to include the distinction between same-sex and different-sex spouses for the person responsible for the domicile in its questionnaire. In this context, this research seeks to advance the scant literature on the subject using the unprecedented 2013 National Health Survey (PNS), which like the 2010 census presents a nationwide comprehensive set of socioeconomic characteristics. Also, the PNS contains information on the health of the Brazilian population and anthropometric measures, which allows the expansion of the controls associated with human capital variables. Part of the results corroborate findings in the international literature where wage differentials in favor of lesbians were observed when compared to their sexual counterparts.
\end{abstract}

- We thank two anonymous referees, and the editor for helpful comments and suggestions. We also appreciate the feedback received during seminar (Federal University of Sergipe) and conference presentations (ABEP 2019, ABET 2019 and XXIII Meeting of Economy of the Southern Region Anpec Sul). This study was financed by CNPq, from CNPq Universal Call/MCTI n ${ }^{\circ}$ 01/2016 for Applied Humanities, Social and Social Sciences, Process $n^{\circ}$ 406564/2016-7. The views expressed herein are those of the authors and do not necessarily reflect the views of either of the institutions to which the authors are affiliated.

1 Analista de Políticas Públicas - Instituto de Pesquisa e Estratégia Econômica do Ceará (IPECE). End.: Av. General Afonso Albuquerque Lima, S/N, Edifício SEPLAG, Térreo, Cambeba - Fortaleza/ CE - Brasil - CEP: 60822-325 - E-mail: daniel.suliano@ipece.ce.gov.br - ORCiD: https://orcid. org/0000-0002-6550-6139.

2 Economista-Chefe- Tribunal de Contas do Estado do Ceará (TCE/CE). End: Rua Sena Madureira 1047, Centro - Fortaleza/CE - Brasil - CEP: 60055-080 - E-mail: jaimefilho@gmail.com. ORCID: https://orcid.org/0000-0003-3646-6585.

3 Professor - Universidade Federal do Ceará - Departamento de Economia Aplicada e do Programa de Pós-Graduação em Economia, CAEN/UFC - End: Av. da Universidade, 2762, $2^{\circ}$ andar - Fortaleza, Ceará, Brasil - CEP: 60020-181 - E-mail: irffi@caen.ufc.br - ORCID: https://orcid.org/00000002-3558-7628.

Recebido: 27/03/2020. Aceito: 20/10/2020.

Editor Responsável: Fabio Waltenberg

(c) (i) (\$) Esta obra está licenciada com uma Licença Creative Commons Atribuição-Não Comercial 4.0 Internacional. 


\section{Keywords}

Sexual orientation. National Health Survey (PNS). Anthropometry. Wages.

\section{Resumo}

Neste trabalho são analisados os diferenciais de salário com base na orientação sexual. Até então, os incipientes estudos que discorreram sobre o tema no Brasil vinham utilizando o censo demográfico de 2010 realizado pelo Instituto Brasileiro de Geografia e Estatística (IBGE). No entanto, a implantação do Sistema Integrado de Pesquisas Domiciliares (SIPD) nas pesquisas amostrais do IBGE passou a incluir no seu questionário a distinção entre cônjuges de sexo distinto e cônjuges do mesmo sexo com relação à pessoa responsável pelo domicílio. Nesse contexto, o trabalho procura avançar na escassa literatura do tema utilizando a inédita Pesquisa Nacional de Saúde (PNS) de 2013 que, assim como o censo de 2010, apresenta um amplo conjunto de características socioeconômicas, de abrangência nacional. Além disso, a PNS contém também informações sobre o estado de saúde da população brasileira e medidas antropométricas, o que permite ampliar os controles associados às variáveis de capital humano. Parte dos resultados corroboram a literatura internacional onde foram observados diferenciais salariais em favor das mulheres lésbicas vis-à-vis as suas contrapartes sexuais.

\section{Palavras-Chave}

Orientação sexual. Pesquisa Nacional de Saúde. Antropometria. Salários.

\section{Classificação JEL}

J12. J20. J22.

\section{Introduction}

Demographic transformations and distinct family arrangements have been causing changes in family structures both in Brazil and in various countries around the world. In the field of demographics, the reduction in fertility and child mortality rates is notable, as well as the increase in life expectancy. Deaton (2017) notes that life expectancy has risen worldwide, even in countries with low per capita incomes, due to scientific progress and new medical discoveries.

In the sphere of family arrangements, paradigm shifts related to sexual orientation have facilitated same-sex marital unions. For example, since 1998 the Netherlands has recognized civil unions between homosexuals and allowed them to marry in 2001. In Brazil, when judging the Direct Action of Unconstitutionality (ADI) 4277 in 2011, the Supreme Federal Court (STF) recognized the stable union of same-sex couples. 
From the perspective of economics, institutional changes in the conditions regarding nuptiality play a major role to the extent that the family is a decision-making entity. According to Becker (1976), intra-family decisions have useful interdependent functions with interaction among family members concerning decisions about children, the division of labor, working hours, the protection of members from danger, and long-term decisions such as intergenerational asset transfers.

It is in this context that the literature approaches the marital union as a decision-making unit that maximizes the couple's utility from the management of domestic activities and those associated with the labor market. In other words, the family unit's utility is derived from decisions about what to consume and how to produce so that the latter choice is a result of the time spent working to acquire goods not produced by household tasks.

Within this economic spectrum, Becker (1991) describes the existence of a marriage market in which men and women compete in search of a partner to establish a family. Thus, each agent decides to marry if the expected utility exceeds that of remaining single or even pursuing a more suitable mate. Therefore, the returns of marriage depend on the comparative advantages of each agent, or even on the complementarity between men and women in the labor market and domestic activities. Thus, evolutionary aspects and cultural tradition have led women to be the main producers of domestic services and childcare, while men are more likely to carry out activities in the market to provide goods.

Within this compass, same-sex couples are less efficient, as it is impossible to benefit from the comparative advantages arising from sexual differences. On the other hand, the absence of an implicit gender-based division of household chores may lead to a greater equalization of the partners' productivity, thereby increasing the number of hours worked and widening the family's productive frontier.

Studies analyzing sexual orientation in the Brazilian labor market are still embryonic, due to the limited availability of databases. More specifically, the economic analysis of sexual orientation in Brazil is restricted to the 2010 Population Census, conducted by the Brazilian Institute of Geography and Statistics (IBGE). 
Despite this narrow database, some studies have investigated the theme, each with different approaches. Corrêa, Irffi, and Suliano (2012) studied the wage differentials between same-sex and different-sex spouses in three Brazilian states with very distinct characteristics, while Casari, Monsueto, and Duarte (2013) estimated the quantile regressions concerning the income gap between heterosexuals and homosexuals. Suliano et al. (2016), in turn, estimated the wage differential of couples in Brazil based on sexual orientation, and Jacinto et al. (2017) investigated discrimination against homosexuals involving their participation in the labor market and the number of hours worked.

On the other hand, IBGE (2014a) highlights structural changes resulting from the reformulation of its household sample surveys through the implementation of the Integrated Household Research System (SIPD). The SIPD is a model for the production of household sample surveys aimed at the planning, execution, analysis, and dissemination of its results in a coordinated manner and currently involves the Continuous National Household Sample Survey (PNAD Continuous), the Family Budget Survey (POF) and the National Health Survey (PNS).

Against this background, the present work employs various mechanisms to contribute to the scarce literature on sexual orientation in Brazil. Initially, the 2013 National Health Survey (PNS) was used which, like the 2010 census, presents a broad set of socioeconomic characteristics about the national workforce.

Furthermore, the PNS gives information on the Brazilian population's health, allowing the controls associated with human capital variables to be expanded, as, since the seminal works of Schultz (1960), Becker (1964) and Mincer (1974), the only variables used have been the years of schooling (education) and proxies for experience (age).

In fact, regarding labor, under the neoclassical paradigm higher pay is directly associated with education, due to the greater expertise acquired by the individual over time and their increased productivity. Also, there is an increase in their cognitive capacity and an improvement in their skills. Furthermore, Ramos (2015) also notes that education's externalities go far beyond labor productivity, with impacts on the reduction in child mortality, the individuals' epidemiological profile in adult life, and unhealthy lifestyle habits. 
A broader and more multifaceted measure of human capital can relate variables associated with physical well-being, individual health, and anthropometric metrics to productivity and wage gains or even discriminatory mechanisms.

Indeed, using data from the National Longitudinal Survey of Youth (NLSY), Averett and Korenman (1993) found salary penalties of around $20 \%$ for obese white women. Cawley's (2004) study of the same database indicates that as well as white women, black women and Hispanic men and women also tend to earn less compared to their thinner peers.

Additionally, according to Case and Paxson (2006), height can be used to understand long-term health consequences as it partly results from prenatal and early childhood environmental conditions. Also, Schultz (2005) reports that height is a good proxy for nutritional and uterine health status and has been widely regarded as an important determinant of chronic adult problems, particularly cardiovascular diseases and illnesses associated with longevity. It can also be used as a measure for marginal wage gains. Wong et al. (2002) present evidence that adults who dropped out of high school are more likely to die prematurely from cardiovascular disease, cancer, infections, lung disease and diabetes.

In Brazil, Curi and Menezes-Filho (2008) observed that height has a significant impact on the completion of school cycles and increases the likelihood of working in occupations that require higher qualifications. Suliano, Irffi and Corrêa (2017) highlight that height and weight act positively on salary gains and Carrilo et al. (2017) show that body weight has a positive effect on wages and the probability of formal employment. Also, Oliveira, Silveira, and Netto Balbinotto (2017) used PNS data to show that cardiovascular disease can considerably reduce earnings. Finally, studies of sexual orientation by Clain and Leppel (2001) also underscore that the inclusion of health status variables avoids potential bias in the estimates.

In addition to this introduction, this article is comprised of five sections. In the next section, we present a discussion of family production from an economic perspective, as well as a review of the literature based on sexual orientation and studies with anthropometric measurements. The next section gives evidence differentiating between homosexuals and heterosexuals in terms of the labor market and anthropometric and health characteristics; it also describes the econometric strategy used in the esti- 
mations. The results and discussions are analyzed before ending with the final considerations.

\section{Discussion of family production model, sexual orientation and anthropometric and health measurements}

\subsection{Family production model}

In a family production model, the members' choices maximize the household's utility so that time is allocated for remuneration in the labor market and household and leisure activities, based on the preferences of household members. Factors such as additional disposable incomes (such as government transfer programs) and relative wage rates can affect some of the decision-making processes.

The model can be expanded to include choices regarding the number of children, which will entail expenses for clothing, food, education, and especially the cost of giving offspring care and attention. In economic terms, this decision mainly depends on family income and the relative price of the good (number of children vis-à-vis other goods and services).

Thus, from an economic viewpoint, the family, embodied in marriage, is a production unit that uses the marriage contract to meet the needs of its formative members. Much of this model's structure was pioneered by Becker (1965, 1973, 1974, 1976, 1991).

The allocation of time between the labor market, leisure, and domestic commodities can be grouped into two choices to the extent that the demand for leisure represents the counterpart of the supply of labor. In this sense, domestic production is a decision-making process about the supply of family labor in which the couple seeks to organize the amount of time between labor activities and the production of domestic services.

Several factors determine the allocation of time between domestic work and the labor market, and economic theory is unclear as to how the division of labor will occur between the couple, regardless of sexual orientation. 
According to Becker (1991), for biological reasons, women tend to have a comparative advantage in domestic production and men in labor supply activities. Also, greater socialization skills lead women to be more productive in child-rearing. ${ }^{1}$

Gronau (1976) demonstrates that American mothers allocate more time to working at home because of the higher relative prices of the services associated with domestic activities (maids, nursery school). In Brazil, Tavares (2010) notes the existence of an income effect resulting from income transfer programs and lower engagement in the labor market.

Despite this evidence, postwar technological changes have greatly influenced incentives for domestic production and specialization. Washing machines, microwaves, vacuum cleaners, ready-prepared foods, and, more recently, digital technologies have incentivized the outsourcing of domestic work and increased work activity.

According to Hoffmann and Leone (2004), in the 1980s and 1990s, the participation of women in Brazilian economic activity and their contribution to household incomes rose continuously. Blau and Kahn (2007) use data from the USA's Current Population Survey (CPS) for the same period to demonstrate a lower sensitivity of the female labor supply vis-à-vis their husbands' salaries.

From another viewpoint, discriminatory processes and the creation of stereotypes that harden over the years can lead to lower wages for a female spouse tending to "push" her into childcare and therefore greater efficiency in caring for offspring, if there is a comparative advantage. In this context, even institutional mechanisms such as maternity leave legislation may encourage employers to discriminate against potential pregnant women due to decreased productivity and women's shorter tenure.

\subsection{Sexual orientation literature review}

In studies of sexual orientation, Ozeren (2014) reveals that heterosexual women are more likely to assume domestic responsibilities, thus opting for

\footnotetext{
${ }^{1}$ Cortes, Jaimovich and Siu (2018) find evidence of a relative increase in the demand for female skills due to their higher social skills.
} 
part-time jobs so that they can reconcile household chores and professional activities. On the other hand, lesbians have a higher probability of being employed full-time. Black, Sanders, and Taylor (2007) also highlight that even in the face of changing gender roles in recent decades, heterosexual families continue to adopt traditional roles, with the women in these partnerships still specializing in domestic production.

More recently, Dilmaghani (2017) found evidence that gay couples' higher family incomes, when compared to heterosexual couples, result from their lower degree of specialization. Also, lesbians have a salary premium due to the greater supply of labor as they can work more hours.

In this context, a wide literature on sexual orientation wage differentials is being consolidated in academic research, despite the restrictions of databases. Initially, these limitations were due to legal, cultural, and social elements.

A pertinent example is a pioneering study by Badgett (1995), in which it was necessary to pool data from the years 1989, 1990, and 1991 of the GSS. Although the database has a process to identify sexual orientation from behavior, given the norms in force at the time it is difficult to infer whether the participants in the sample could spontaneously disclose their preferences regarding sexuality.

However, a growing economic literature on sexual orientation, especially in the United States, has been consolidating results in which wage differentials are unfavorable to gay men and favorable to lesbians when compared to their gender counterparts. See, for example, Badgett (1995); Klawitter and Flatt (1998); Jepsen (1999); Allegretto and Arthur (2001); Clain and Leppel (2001); Berg and Lien (2002); Black et al. (2003); Blandford (2003); Carpenter (2005); Carpenter (2007); Antecol, Jong and Steinberger (2008).

Other results, such as Plug, Webbink, and Martin (2014) show that the occupational choices of gay men and lesbians are determinants of income differentials. Indeed, according to Ahmed, Andersson, and Hammarstedt (2013b), even in Sweden, a country that has a more liberal and tolerant public opinion, homosexuals have problems entering the labor market. Under such conditions, the labor market may become a mechanism that 
transforms individual characteristics into income inequality. Segmentation and discrimination are the channels that reveal this transmission.

In a segmented labor market, workers with perfect substitutability in terms of productivity are paid differently because they are employed in different jobs. Accordingly, Blanford (2003) observed that while lesbian and bisexual women are successful in typically male-dominated occupations, gay and bisexual men are allocated predominantly female-identified occupations, depressing their human capital returns.

The literature on sexual orientation gives also evidence of discrimination. Klawitter and Flatt (1998) observed that same-sex couples are more likely to live in regions of the United States that have anti-discrimination policies.

Studies using different methodologies in European countries also reinforce the existence of discrimination, especially regarding gay men. In the United Kingdom, Calandrino (1999), in addition to unfavorable wage differentials, detected differences in employability and fewer opportunities for career advancement. In Turkey, Ozturk (2011) collected reports from individuals identified as homosexual or bisexual and found widespread discrimination in various work environments. Humpert (2016) highlights the hostility suffered in Germany as more homosexuals rise to positions of power.

In another respect, Becker (1991) argues that differences in opportunity cost between the sexes lead to different degrees of specialization in which a lack of comparative advantage makes same-sex couples less likely to be efficient in this type of arrangement. On the other hand, Badgett (1995) considers that the indifferent marginal product between homosexual individuals results in a potential advantage in their set of productive opportunities.

Ahmed, Andersson, and Hammarstedt (2013a) found that lesbians have higher earnings than heterosexual women, especially at the top of income distribution, due to their increased dedication and time for working activities. For Giddings et al. (2014), there is still no evidence of the existence of a specialization gap based on couples' sexual orientation. They argue that same-sex couples are less likely to exhibit a higher degree of specialization than those of different genders, although more recent birth cohorts 
of the former resemble the latter more closely because of the advent of reproductive technologies.

Furthermore, Antecol and Steinberger (2013) state that although married men are spending more time in the production of childcare, evidence indicates that married women continue to allocate more time to this activity than their spouses. The authors discuss the sociological literature and attest that married women are more likely to identify with domestic production and work activities, while married men only identify with the latter.

From this perspective, Gough and Noonan (2013) found that maternity leads to a five to ten percent penalty per child in women's salaries. According to Lafrance, Warman, and Woolley (2009), children tend to widen the traditional division of labor within the home because women specialize in childcare and married men devote more time and effort to paid work to support the children.

In studies such as Oreffice's (2007), intra-family bargaining power is a Pareto-efficient decision when associated with social and legal factors such as non-work income, age, and age differential. In line with these results, Oreffice's (2011) evidence is that labor in gay and lesbian households is affected by bargaining power and that these couples behave similarly to couples of different genders where job supply responds to differences in age and non-work income.

\subsection{Anthropometric and health measurements evidence}

Economic literature has also highlighted the effects of anthropometric variables on the job market. According to Harper (2000), there is an association between measurements of height and weight and an economic return in the labor market. More specifically, it was observed that men and women of short stature experienced salary disadvantages, while those considered obese were less likely to marry; among men, shorter males had a lower rate of marriage frequency.

According to Hakim (2012), height is a measurement that merges elements ranging from cognitive ability to social skills. According to the author, all 
cultures widely consider tallness a positive characteristic, especially for men. Furthermore, in childhood, social processes favor taller children by shaping their personalities so that when they reach adulthood they are more confident and have greater social skills. In the workforce, the evidence shows that height increases wage gains from $10 \%$ to $20 \%$.

Schultz (2005) also notes that estimates of wage functions that include adult height based on household surveys confirm the associations between wages and productivity, as well as an earning disadvantage for those of short stature. Schultz also states that these results have already been highlighted by economic historians and anthropologists. ${ }^{2}$

The association between obesity, health, and earnings is also the object of investigation in economic studies, as observed by McLean and Moon (1980), although they did not find evidence of salary disadvantages in obese men with experience in the labor market. On the other hand, weight loss directly impacts human capital measures through its effects on professional longevity.

In addition to the effects on income differentials, for women weight, measured by the Body Mass Index (BMI), impacts on marital status and discrimination within the labor market. Averett and Korenman (1993) observed that obese women had a lower family income compared to those who had adequate BMI. They are also penalized in the marriage market. Caliendo and Gehrsitz (2014) also used women's BMI in semi-parametric regressions; rather than finding a penalty for obesity they observed a "thinness premium".

However, Cawley and Burkhauser (2006) highlight a broad consensus in the medical literature regarding the use of BMI as a metric because it does not differentiate between fat and muscle mass. Instead, they used more precise measurements of body fat, such as percentages, absolute values, and waist circumference, and found that individuals with more fat were at a higher risk of incapacity for the labor market, whilst workers with a

2 According to Ferguson (2012), at the end of the eighteenth century, more than 28\% of English rural workers' diets consisted of products of animal origin; their Japanese counterparts, on the other hand, lived on a diet made up of 95\% cereals, mainly rice. According to this author this nutritional difference explains the marked differences in stature after 1600. The average height of English convicts in the eighteenth century was 1.69 meters, whereas the average height of Japanese soldiers in the same period was only 1.58 meters. Currie and Vogl (2013) also note that taller workers are healthier and stronger. 
high body mass and a lower percentage of adipose tissue had a lower risk of disability.

In Brazil, there is evidence of various impacts on the labor market for height and weight measurements. Curi and Menezes-Filho (2008) analyzed the influence of height on education and the labor market, showing positive and significant effects on school cycles, performance in the primary job, and the allocation of workers among occupations.

Carrilo et al. (2017) observed positive effects of weight on wages and the probability of formal employment. Using instrumental variable techniques, they found that higher wages and a reduced probability of informal employment were associated with a higher BMI, especially in women and non-white individuals in urban areas. ${ }^{3}$

Anthropometric measures are still scarce in studies that analyze wage differentials based on sexual orientation. Clain and Leppel (2001) used health status as a control to identify the possible effects of disability and illness (including HIV) on individual productivity.

Klawitter's (2015) meta-analysis of studies between 1995 to 2012 relating sexual orientation and income identified a single study using controls for health variables in which it was not statistically significant, even if the use of these controls resulted in major changes in the size or significance of other coefficients when the variables were added.

\section{Some evidence and methodological Strategy}

\subsection{Descriptive analysis of the characteristics based on sexual orientation}

Table 1 shows the population distribution according to sexual orientation, using spouses as a parameter as the variable condition in the home. As part of the core of the Integrated System of Household Surveys (SIPD) of the

3 Using data from the 2012 National School Health Survey (PeNSE), Kubota (2014) notes that students who declare themselves "very fat" or "very thin" are more prone to at-risk behavior, such as the consumption of illicit drugs, alcohol, cigarettes and laxatives (or inducing vomiting) and more likely to suffer from bullying. 
IBGE, the PNS, like the 2010 demographic census, differentiates between same-sex and different-sex spouses in its questionnaire. From this distinction, it is possible to deduce the sexual orientation of both the spouses and the person responsible for the household (head of the family). As a result, the consensual union of couples where the spouse has a different gender is defined as heterosexual and the cohabitation of couples where the spouse is of the same gender is classified as homosexual. ${ }^{4}$

According to Allegretto and Arthur (2001), this is an indirect identification method, although it is a viable means of observing sexual orientation. It is the most readily available data source in studies that analyze the wage differential between homosexuals and heterosexuals.

When this identification process was adopted in the United States, from the 1990 American census, Black, Sanders, and Taylor (2007) pointed out that this is the only possible way to obtain large-scale samples of same-sex couples. Previously, American research on this theme used the GSS ${ }^{5}$ of individual behavior to identify any sexual relationship with a same-sex partner aged 18 and over. According to Klawitter (2015), other developed countries, such as Australia, Canada, France, Greece, Holland, United Kingdom, and Sweden, have been using questions about the gender of sexual partners (sexual behavior) and sexual identity (self-identification of people as heterosexual, homosexual or bisexual) in their databases, thus permitting other processes to identify sexual orientation. ${ }^{6}$

According to the 2013 PNS, there are a total of 92.3 million people distributed among heterosexuals (men and women), homosexuals (men and women), and single. ${ }^{7}$

4 Saboia, Cobo and Matos (2012), when discussing the changes introduced in the 2010 Census questionnaire and the SIPD member databases, emphasize that the differentiation between spouses of the same gender and spouses of different genders allows the quantification of households with partnerships or couples who are of the same sex.

5 Badgett's (1995) influential article used the GSS. Another American survey, the 1992 National Health and Social Life Survey (NHSLS), also collected information on individuals' sexual practices enabling the identification of sexual orientation based on behavior. Zavodny (2007) used GSS and NHSLS data. More recently, Davidowitz (2018) is using data science to refute some GSS results. He also notes underreporting of homosexual behavior in those American states where there is greater intolerance.

6 As well as using spouses to identify sexual orientation (consensual union), Suliano, Irffi and Barreto (2019) identify three other forms of sexual orientation: sexual behavior, self-declaration (selfidentification) and militancy (conducting an experiment to send resumes to companies).

7 According to the IBGE (2014b), population target are private individuals resident of households in Brazil, except those located in the census sectors (quarters, military bases, accommodations, camps, vessels, penitentiaries, penal colonies, prisons, jails, asylums, orphanages, convents, and hospitals). 
Regarding gender, women are predominant with a total of 58.5\%, of whom slightly less than $75 \%$ are heterosexual, around $25 \%$ single, and only $0.22 \%$ homosexual. Of the $41.5 \%$ men, heterosexuals are also the majority with $85.7 \%$ of the total, followed by $14 \%$ of singles and $0.20 \%$ of homosexuals. ${ }^{8}$

Table 1 - Population Distribution by Sexual Orientation

\begin{tabular}{c|c|c|c|c|c|c|c}
\hline \multirow{2}{*}{ Gender } & \multicolumn{2}{|c|}{ Heterosexual } & \multicolumn{2}{c|}{ Homosexual } & \multicolumn{2}{c|}{ Single } & Total \\
\cline { 2 - 8 } & Quantity & $\%$ & Quantity & $\%$ & Quantity & $\%$ & Quantity \\
\hline Men & $35,973,746$ & 85.75 & 85,136 & 0.20 & $5,890,767$ & 14.04 & $41,949,649$ \\
$\%$ & 48.82 & -- & 43.71 & --- & 31.96 & $\cdots$ & 41.50 \\
Women & $37,715,818$ & 74.88 & 109,652 & 0.22 & $12,543,646$ & 24.9 & $50,369,116$ \\
$\%$ & 51.18 & -- & 56.29 & --- & 68.04 & --- & 58.50 \\
\hline Total & $73,689,564$ & 80.32 & 194,788 & 0.21 & $18,434,413$ & 38.94 & $92,318,765$ \\
\hline
\end{tabular}

Source: Prepared by the authors using the expansion weight of the PNS 2013 sample data.

Table 2, in turn, shows characteristics regarding age and the labor market. Gay men and lesbians are younger than their heterosexual counterparts, with the former having an average age of 36 and 34, while the latter average 43 and 40 , respectively.

The initial evidence from Table 2 supports the hypothesis that, in the case of lesbians, the job offer for homosexuals is higher than that for heterosexuals (men have an identical average of 38 hours).

From the same point of view, it can be observed that even working the same number of hours gay men earn, on average, more than heterosexuals. According to the 2013 PNS, the average income of the former was $\mathrm{R} \$ 2,805.54$, while heterosexuals earned only $\mathrm{R} \$ 2,057.47$. The average salary of heterosexual women is only $75.8 \%$ of lesbians' salaries.

The sample of the 2013 PNS is a subsample of the master sample of the SIPD, whose geographical scope is constituted by the census sectors of the geographic operational base of the 2010 Population Census, except those with a very small number of households and special sectors. In this sample, there was an age cutoff including only 18-65-year-olds. IBGE estimated the total population of Brazil at 201.03 million people in 2013.

8 These results are in line with the sexual orientation literature [see, for example, Badgett's (1995), Allegretto and Arthur (2001), Black, Sanders and Taylor (2007), Antecol, Jong and Steinberger (2008), Suliano et al. (2016)]. 
Table 2 - Demographic Characteristics and Labor Market

\begin{tabular}{l|c|c|c|c}
\hline \multirow{2}{*}{ Demographic Indicator and Labor Market } & \multicolumn{2}{|c|}{ Men } & \multicolumn{2}{c}{ Women } \\
\cline { 2 - 5 } & Gay & Heterosexual & Lesbian & Heterosexual \\
\hline Average age & 36 & 43 & 34 & 40 \\
\hline $\begin{array}{l}\text { Number of hours normally worked in the main job and other } \\
\text { jobs(s) }\end{array}$ & 38 & 38 & 32 & 20 \\
\hline $\begin{array}{l}\text { Average monthly gross income normally received in the main } \\
\text { job or that you take monthly from that job plus the gross } \\
\text { monthly income or normal receipt from other jobs(s) in July } \\
2013 .\end{array}$ & $2,805.54$ & $2,057.47$ & $2,024.57$ & $1,535.07$ \\
\hline
\end{tabular}

Source: Prepared by the authors from the PNS 2013 sample data.

Some of the results from the previous table are in line with the classical theory of human capital originally proposed by Schultz (1960) and Becker (1964) under the neoclassical paradigm, which ensures higher wage premiums in the labor market through the productivity gains of those with higher educational levels. In this context, Table 3 shows the percentage of men and women by sexual orientation concerning the completed schooling cycle.

There is a clear difference in the 2013 PNS sample about schooling cycles according to sexual orientation. Homosexual men and women have predominantly completed high school (35\% and $42 \%$, respectively), while heterosexual men and women had higher percentages among those who completed elementary school (41.8\% and $36.5 \%$, respectively).

Moreover, the percentage of gay men who have completed higher education is more than the double of heterosexual males (29\% versus $13.8 \%$, respectively). Lesbians also have a higher percentage than heterosexual women in the higher education cycle ( $24.4 \%$ versus $15.7 \%$, respectively). 
Table 3 - Schooling Level by Schooling Cycle

\begin{tabular}{l|c|c|c|c}
\hline \multirow{2}{*}{ Level of Schooling } & \multicolumn{2}{|c|}{ Men } & \multicolumn{2}{c}{ Women } \\
\cline { 2 - 5 } & Gay & Heterosexual & Lesbian & Heterosexual \\
\hline No Schooling and Incomplete Elementary School & 2.0 & 1.0 & 1.7 & 0.0 \\
\hline Elementary Complete and High School Incomplete & 14.0 & 41.8 & 16.3 & 36.5 \\
\hline High School Complete / Higher Education Incomplete & 35.0 & 31.2 & 41.9 & 33.7 \\
\hline Higher Education Complete & 29.0 & 13.8 & 24.4 & 15.7 \\
\hline No declaration & 21.0 & 11.2 & 17.5 & 12.4 \\
\hline
\end{tabular}

Source: Prepared by the authors from the PNS 2013 sample data.

Finally, Table 4 describes the variables demonstrating anthropometric measurements and that indicate health-related effects, variables that may be associated with a wider measurement of human capital. As can be observed, as far as the variable of intellectual disability is concerned the effects are not relevant, especially among homosexuals.

Both gay men and lesbians recorded higher percentages regarding the use of health insurance. Also, the results in Table 4 reveal that both health status and physical exercise or sports activities over the past three months differentiate homosexuals from heterosexuals with a noteworthy difference in the percentages.

In the case of health status, $81 \%$ of gay men consider their health to be good or very good compared to $70.3 \%$ of heterosexuals. The difference is less significant for women (69.4\% against $65.6 \%)$. There is also a relevant difference for men regarding exercise.

Anthropometric measurements indicate that gay men are on average taller and slightly thinner. Lesbians, in turn, are slightly taller and heavier than their gender counterparts. 
Table 4 - Anthropometric and Health Measures

\begin{tabular}{l|c|c|c|c}
\hline \multirow{2}{*}{\multicolumn{1}{c|}{ Health }} & \multicolumn{2}{c|}{ Men } & \multicolumn{2}{c}{ Women } \\
\cline { 2 - 5 } & Gay & Heterosexual & Lesbian & Heterosexual \\
\hline Good or very good health (\%) & 81.0 & 70.3 & 69.4 & 65.6 \\
\hline Private health insurance (\%) & 42.0 & 27.2 & 31.3 & 28.4 \\
\hline Intellectual disability & 0.0 & 0.1 & 0.0 & 0.1 \\
\hline Exercise or sport in the last three months (\%) & 47.6 & 34.1 & 29.2 & 23.9 \\
\hline Average height in meters & 1.75 & 1.71 & 1.61 & 1.60 \\
\hline Average weight $(\mathrm{kg})$ & 77 & 78 & 69 & 67 \\
\hline
\end{tabular}

Source: Prepared by the authors from the PNS 2013 sample data.

\subsection{Econometric strategy used}

As seen above, the labor supply is the result of a utility maximization problem that is empirically translated by a wage equation originally deduced by Mincer (1974), in which the labor wage logarithm is the dependent variable, which in this case was obtained through the gross monthly income normally received in the main job or monthly withdrawn in that job added to the gross monthly income earned or monthly withdrawn in other jobs $(s)$ in July 2013. ${ }^{9}$ Also, there was an age cutoff, so that only 18-65-year-olds were included to absorb the maximum members of the workforce.

To ascertain the differences in remuneration based on sexual orientation, a dummy was used for the couple for both men (gay) and women (lesbians). The control used a set of characteristics associated with demography, geography, and the labor market $(x)$ as well as a broad measure of human capital (ch), which in addition to the traditional measures of schooling

9 The use of a labor wage logarithm as a dependent variable was the practice adopted. In his empirical representation of the wage equation based on the theoretical model of labor supply, Mincer (1974) does not specify whether the wage logarithm should be expressed in annual, monthly or hourly earnings. One of the functional forms of the wage equation establishes a relationship throughout the life cycle between annual earnings and hours of work as a dependent variable. Menezes-Filho (2002), when discussing the functional form of dealing with methodological issues associated with the estimation of the income equation, never addresses the specification of the dependent variable, which implies that in the context of the discussion it is not a specification problem. Ueda and Hoffmann (2002) use the Napierian logarithm of all the jobs of employed people. In the article that discusses sexual orientation in Brazil, Suliano et al. (2016) estimate the differentials based on sexual orientation using the main job's gross monthly income. 
includes those associated with anthropometry and individual health.$^{10}$ In addition, $w_{i}$ describes gross monthly income of all jobs ${ }^{11}$ and $\varepsilon_{i}$ represents an error term.

$$
\ln \left(w_{i}\right)=\alpha g a y / \text { lesbians }+\beta x_{i}^{\prime}+\gamma c h_{i}^{\prime}+\varepsilon_{i}
$$

The explanatory variables used were related to workers' characteristics, labor market variables, and the main Brazilian regions.

In the category of the individual's skin color, separate dummies were added for whites, those who self-identified as black/brown, and those who declared themselves yellow, as a way to obtain a difference in the mean for indigenous people (category omitted).

For the labor market, following the work of Mincer (1974), age, measured in years, was used as a proxy measure of experience in addition to its quadratic term to observe the decreasing marginal effects up to a maximum point of the worker's age. Additionally, per Hoffmann and Simão (2005), the Napierian logarithm of the number of hours worked was used as a control to attain the elasticity of earnings concerning the hours worked.

Five binary variables were also added to distinguish the occupational position of the main job to the home worker. The base categories are civil servant, employee, employer, self-employed, and self-help worker.

Concerning the major regions of residence, individual dummies were added for the northeast region, residents in the southeast region, those residing in the south region and finally, for those residing in the center-west region as a way of differentiating them from residents in the northern region, who were the reference category.

The variables associated with education, health status, and anthropometric measures are a broad measurement of human capital $(\mathrm{ch})$.

\footnotetext{
${ }^{10}$ The variable 'practice of physical exercise or sport in the last three months' was excluded because there was a low number of responses.

11 The results are similar when using hourly earnings.
} 
The PNS database provides data on education according to the study cycle that the person attended. In this way, three dummies were added for the completed education cycles (elementary, high school, and higher education), to differentiate them from those who have not completed a study cycle (even incomplete elementary).

To control the characteristics associated with health, two binary variables distinguish between those who informed a poor or very bad state of health. In this context, one dummy was used for those who declared themselves to be in good or very good health and another for those who stated that their health was regular. A third dummy was added to measure the average difference between those who have health insurance compared to those who do not. Lastly, a fourth dummy differentiated between those who do not have intellectual disabilities and those who declared such a disability.

The controls of anthropometric measures in which the height and weight of the individuals were used in addition to their quadratic terms are noteworthy when considering the impact of these variables on income through a parabolic effect according to Suliano, Irffi and Corrêa (2017).

Since Harper (2000), there is evidence of anthropometric measures in wages within the labor market in the literature. In Harper's work, longitudinal data were analyzed for cohorts of 11,407 individuals born in 1958 in Great Britain, with income gains being observed for men of high stature and salary penalties for obese women, as well as evidence in terms of productivity. Other studies, such as Oreffice and Quintana-Domeque (2016) also highlight the effects of anthropometric attributes on wages. More specifically, Cawley (2004) obtains consistent estimates of the effect of weight on wages, and Case and Paxson (2006) present wage premiums based on an association between height and intelligence.

The estimation of (01) by the Least Squares Method (OLS) tends to have selection bias problems (sample selection) because there are people in the sample who are unemployed and therefore have no salary. Despite the occurrence of structural unemployment, some economic agents have an implicit reserve salary, which serves as a glass ceiling for accepting to work or not. 
If so, the decision whether or not to work depends on comparing the wage offered by the market and the reserve wage in an individual's job search, where inactivity results from either a high reserve wage or low available wage rates. The selection bias problem can be circumvented by incorporating a participation equation using the Heckman (1979) procedure.

\section{Results and discussions}

The results of the estimations are presented in Table $5 .{ }^{12}$ Columns (1), (2), (3) and (4) show the estimates using Ordinary Least Squares (OLS) and columns (5), (6), (7) and (8) use Heckman's method to correct sample selectivity (heckit). The selection equations ( $1^{\text {st }}$ stage) are found in the appendix ${ }^{13}$ (the standard errors are in parentheses).

Also, separate regressions were estimated for men and women. Thus, columns (1), (2), (5) and (6) compare gay men's wage differentials vis-à-vis heterosexuals, while columns (3), (4), (7) and (8) analyze the difference in lesbian's salaries compared to heterosexual females.

In turn, the difference between columns (1), (3), (5) and (7) and (2), (4), (6) and (8) is that the former do not have the controls for the anthropometric variables of height and weight due to the high absence of this information in the PNS database. For men, the sample drops to around $20 \%$ and for women just under $50 \%$.

Regarding the estimates, it is evident that in all the regressions for men no statistically significant differences were found between gay men and heterosexuals. Also, the results in Appendix A for Heckman's first stage regressions (5) and (6) are not well adjusted; there are many standard errors and no significance between the variables.

12 The estimate made use of the PNS 2013 sample data.

${ }^{13}$ In addition to the controls in (01), exogenous variables in the participation equation were used as determinants in the salary offer for children under 18 years and other income than those normally received in the main job or monthly withdrawn in that job and in other work in July 2013. Another variable that can determine the hours worked and which is present in the 2013 PNS questionnaire is participation in organized social activities such as clubs, community or religious groups, residential centers for the elderly etc., which was not included in the participation equation due to the low number of responses. 
In the regressions for women, the estimates using the OLS procedure and the one employing Heckman's anthropometric variables as a control were statistically significant, although in the latter case the variable lambda, which corrects the problem of sample selectivity, is not significant.

Kassouf (1994), using Heckman procedure and OLS, notes that were found an upward biased estimate (in absolute value) for male workers and a downward biased estimate (in absolute value) for female workers.

According to Cameron and Trivedi (2009) OLS regression will not yield consistent parameter estimates because the censored sample is not representative of the population and statistical inference on the estimated parameters of the model also involve significant extensions of the standard theory.

In turn, Leung and $\mathrm{Yu}$ (2000), using Monte Carlo simulations, found the estimator obtained from Heckman (1979) offers a good performance. In fact, according to Hayashi (2000), since inverse Mill's ratio is known under the normality assumption for error, the sample selection bias can be avoided by applying non-linear estimators, although maximum likelihood estimation should be preferred because it is asymptotically more efficient. It is also highlighted that sample selection bias does not occur due to the regressors.

As stated, two exclusion restrictions are imposed in the selection equation (children under 18 years and other income). The hypothesis is that these variables have a substantial impact on the probability of selection and make identification more robust, although it is difficult to observe an excluded variable that does not directly affect the results, though it determines the selection equation.

Furthermore, Heckman (1979) brings up loss of efficiency when compared to the likelihood estimator (MLE), although it is an easy method to implement and has weaker assumptions than the $\operatorname{MLE}^{14}$ [Cameron and Trivedi (2005)].

${ }^{14}$ However, the maximum likelihood method is asymptotically more efficient [see Hayashi (2000)]. 
Some hypotheses may be raised regarding the non-significance of Heckman's method. As stated above, the data used here is from the 2013 National Health Survey, a period in which the Brazilian economy had a reasonable but not sustained growth [see, for example, Giambiagi and Muinhos (2013)].

Also, Castro Souza's (2013) estimates of average national GDP growth based on average potential output growth reveal that after the extraordinary growth in GDP in 2010 the Brazilian economy was beginning to operate at its full potential. Besides, unemployment in the period was essentially structural, with the entire workforce occupied ${ }^{15}$ and therefore, there was a high reserve wage, which may have made the estimates of the heckit non-significant.

In turn, it is worth highlighting that when using data from the Macedonian labor market to analyze gender wage differentials and their discriminatory effects, Petreski, Blazevski, and Petreski (2014) suggest some disadvantages in Heckman's correction procedure for the problem of selection bias by incorporating a participation equation.

In the Macedonian case, women with lower qualifications are paid less than men of the same educational level. Although this may indicate evidence of discrimination, it was observed that the pay gap between educational groups is positively correlated with differences in employment and gender participation within the labor market, which indicates a non-random selection of women.

In this type of situation, the standard heckit correction when there is a selectivity bias suggests that non-random selection exists, but the resulting salary difference remains at the same level, even when the selection is considered.

The regression for women (3) indicates that, on average, lesbians earn $17.5 \%$ more than heterosexual females. The large regions of the country and the variables associated with demographics, work, education, and health were maintained as fixed. When anthropometric measures of height and weight are used as an additional control, as well as their quadratic

${ }^{15}$ Continuous PNAD data show that the unemployment rate in Brazil reached a record low in the fourth quarter of 2013. Available at: https://www.ibge.gov.br/estatisticas-novoportal/sociais/rendimento-despesa-e-consumo/9171-pesquisa-nacional-por-amostra-de-domicilios-continua-mensal. Access on: October 01, 2020. 
terms, lesbian wage gains compared with heterosexual women are, on average, $22.4 \%$ higher, which is a similar result to that of the heckit.

These results are not in line with national studies, although they agree with a wide range of results in the literature. The results observed until that point in Brazil only used data from the 2010 IBGE demographic census. Corrêa, Irffi, and Suliano (2012) used data from spouses for three Brazilian states and found gains of up to $40 \%$ for gay men. For women, the results are in line with the literature, with gains of up to $19 \%$ in favor of lesbians. Similarly, applying quantile regressions, Casari, Monsueto, and Duarte (2013) evidenced positive effects for both gays and lesbians in the metropolitan region of São Paulo, with these gains increasing in the highest income quantiles.

Similarly, Suliano et al. (2016) used the OLS method to show that gay couples earn on average $25.11 \%$ more than homosexual male couples, while by Heckman's method lesbian couples earn $13.84 \%$ more than their gender counterparts. Da Silva and Dos Santos (2016), in turn, revealed that same-sex couples of both genders have higher levels of economic well-being than heterosexual couples.

On the other hand, in Badgett's (1995) seminal work, gay and bisexual men earn up to $27 \%$ less than their heterosexual peers, with no observable differences between lesbians and heterosexual women, although among women the results from the wider study favor the former.

In a meta-analysis of the effects of sexual orientation on income, Klawitter (2015) finds that lesbians earn 9\% more than heterosexual women, with estimates showing that they earn between 25\% to $43 \%$ more. Gay men earn up to $11 \%$ less than heterosexuals with estimates varying between $30 \%$ less or even no salary difference between them. When using the Heckman selection method, the estimates are lower for women and higher (in negative terms) for men.

A systematic review by Ozeren (2014) also notes that gay and bisexual men have lower salary gains than heterosexual male employees. Concerning women, the vast majority of studies analyzed in different contexts (the USA, UK, and Holland) reveal that lesbians earn more vis-à-vis heterosexual women employed in similar positions because of the "lesbian income advantage". 
Suliano, Irffi, and Barreto (2019) use a similar method to highlight the salary penalty suffered by gay men compared to their sexual counterparts, as well as the salary premium for lesbians in contrast to heterosexual women. When analyzing studies that impact income covering twelve countries between 1995 to 2016, it was observed that when compared to their heterosexual counterparts gay men had wage losses ranging from 3\% to $32 \%$. A comparison between lesbians and heterosexual women evidenced that the former had a salary advantage, which varied between $3 \%$ to $30 \%$.

Finally, regarding the other explanatory variables, the results of the marginal effects concerning the control categories had a statistical difference for most of the explanatory variables in the OLS estimates and in some that correct sample selectivity. 


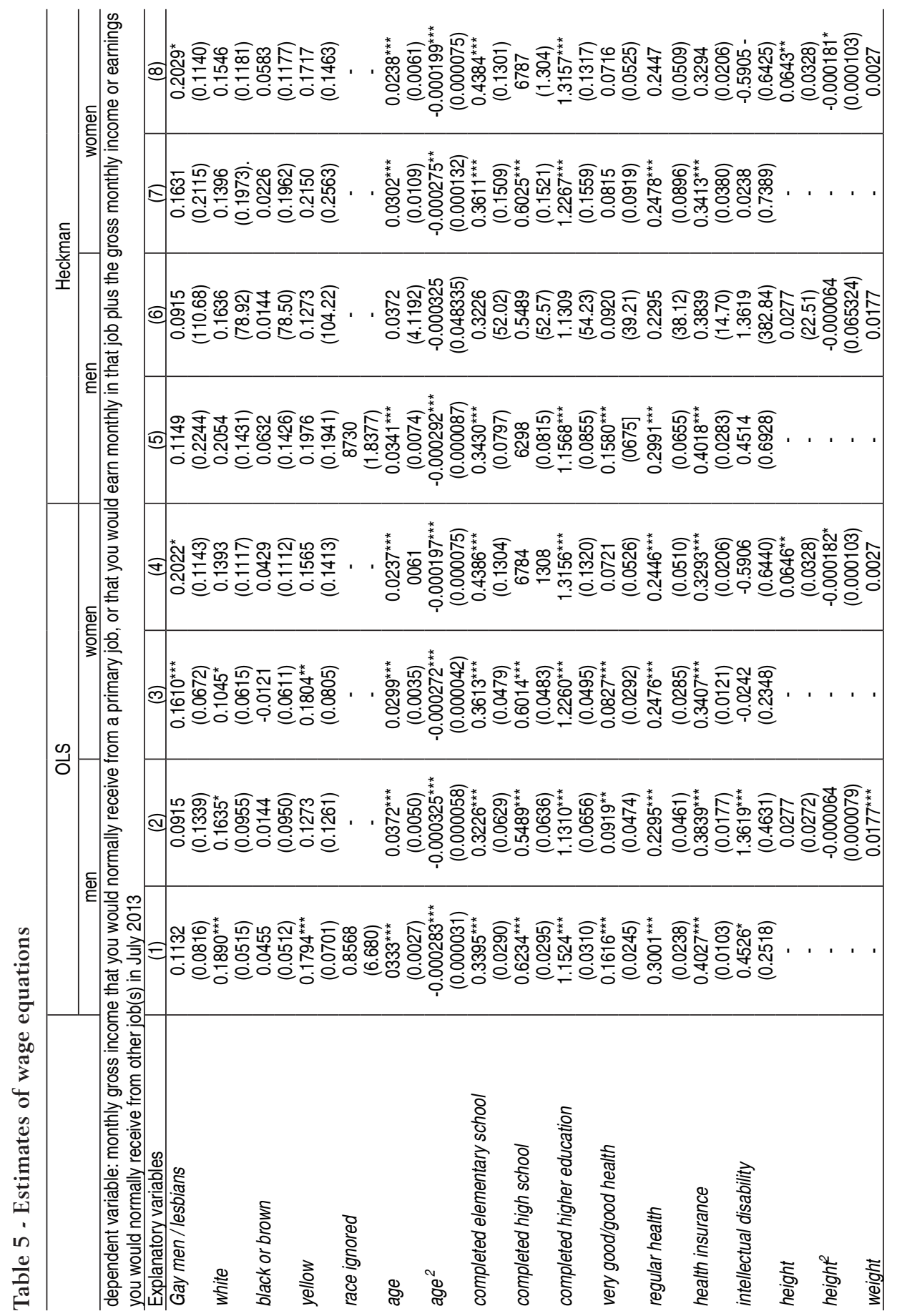




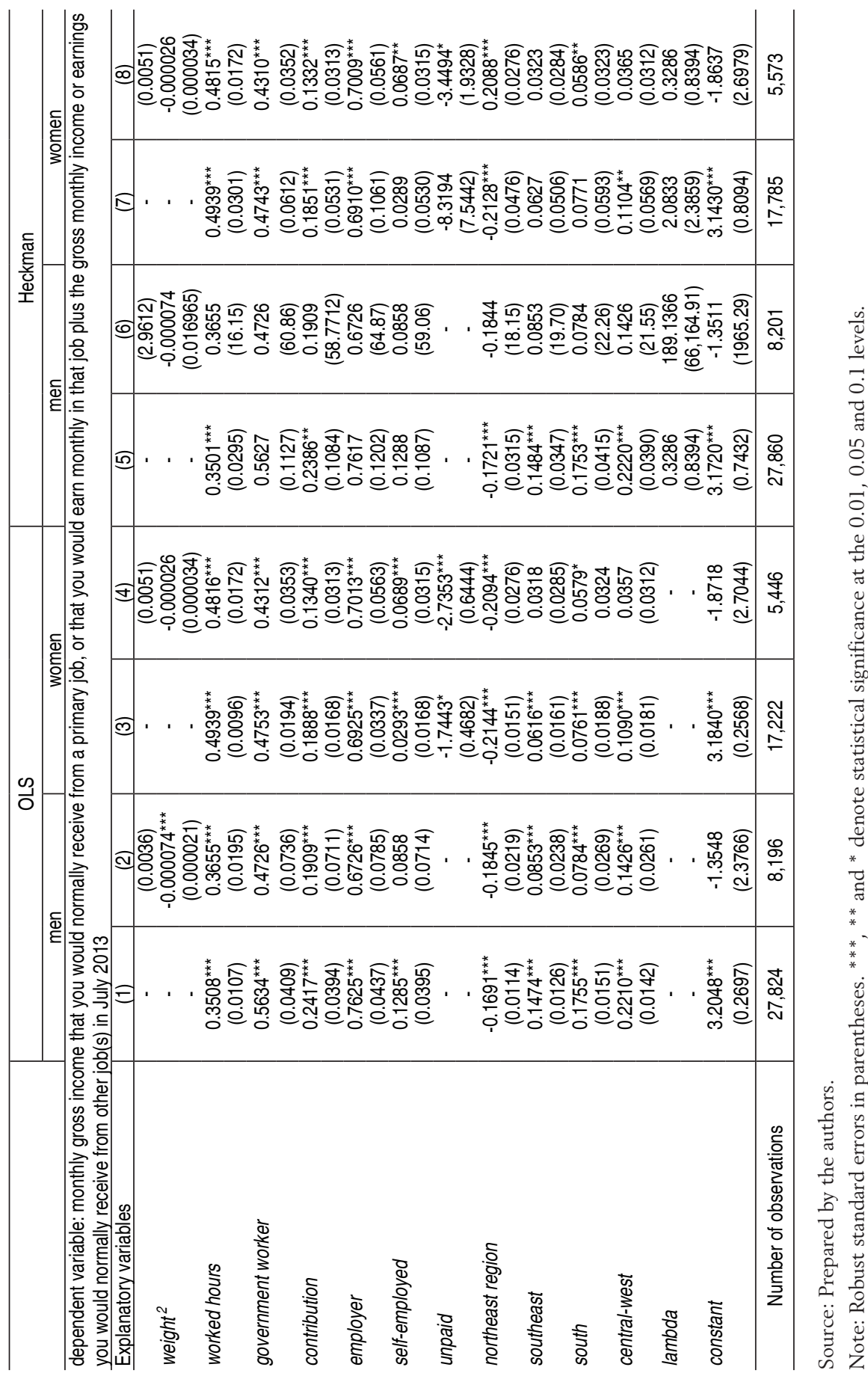




\section{Final remarks}

In Brazil, studies on the topic of sexual orientation are still at an early stage because until recently national household surveys did not identify whether the spouse of the person responsible for the household was of the same sex or not.

So far, studies have focused on the 2010 population census conducted by the Brazilian Institute of Geography and Statistics (IBGE), which was the only research available that made a distinction between heterosexuals and homosexuals in terms of cohabitation.

However, recent structural changes in household sample surveys through the implementation of IBGE's Integrated Household Survey System (SIPD) now identify same-sex cohabiting couples. It is within this context that the present paper sought to analyze wage differentials based on sexual orientation to advance the scarce literature on the subject in Brazil.

Given this context, this study used the unprecedented IBGE 2013 National Health Survey (PNS) which, like the 2010 census, presents a broad set of socioeconomic characteristics in the labor market as well as anthropometric and health measurements.

Thus, the PNS allows the associated controls to be expanded through a more comprehensive measure of human capital. Studies for Brazil, such as Oliveira, Silveira, and Balbinotto Netto (2017) have already shown that health metrics, such as cardiovascular diseases, may reduce salaries. Curi and Menezes-Filho (2008), Carrilo et al. (2017) and Suliano, Irffi, and Corrêa (2017) also observed associations between anthropometric measurements and salary gains. Clain and Leppel (2001) emphasize that the inclusion of health status may prevent potential bias in outcomes of sexual orientation studies.

The results found no statistical differences regarding the salaries of gay men when compared to heterosexual men in all the estimated models. These results are repeated for women when using the two-stage Heckman method without control by anthropometric measurements. On the other hand, when using the height and weight controls, the heckit estimates indicated salary gains for lesbians of around $22.5 \%$, although the variable that corrects the sample selectivity problem was not significant. 
The model's estimates that correct sample selectivity may be associated with the particular juncture of the national macroeconomic environment. The data used corresponds to the year 2013 when unemployment reached a historical low and the economy was close to its potential output. Giambiagi and Schwartsman (2014) analyzed data from the Monthly Employment Survey (PME) during the same period and they highlight the intense warming of the labor market leading to almost full employment in the country. These circumstances may affect both the reserve wage and the participation rate in the labor market.

\section{References}

Ahmed, a. M.; Anderson, 1.; Hammarstedt, M. 2013a. "Sexual Orientation and Full-Time Monthly Earnings, by Public and Private Sector: Evidence from Swedish Register Data". Review of Economics of the Household 11, no. 1:83-108.

Ahmed, A. M.; Andersson, L.; Hammarstedt, M. 2013b. “Are Gay Men and Lesbians Discriminated against in the Hiring Process?” Southern Economic Journal 79, no. 3: 565-585.

Allegretto, S. A.; Arthur, M. M. 2001. "An Empirical Analysis of Homosexual/Heterosexual Male Earnings Differentials: Unmarried and Unequal?” Industrial \& Labor Relations Review 54, no. 3: 631-646.

Antecol, H.; Jong, A.; Steinberger, M. D. 2008. "The Sexual Orientation Wage Gap: The Role of Occupational Sorting and Human Capital”. Industrial \& Labor Relations Review 61, no. 4: 518-526.

Antecol, H.; Steinberger, M. D. 2013. "Labor Supply Differences Between Married Heterosexual Women and Partnered Lesbians: A Semi-Parametric Decomposition Approach”. Economic Inquiry 51, no. 1: 783-805.

Averett, S.; Korenman, S. 1993. The Economic Reality of The Beauty Myth. NBER Working Paper 4.521.

Badgett, M. V. L. 1995. “The Wage Effects of Sexual Orientation Discrimination”. Industrial \& Labor Relations Review 48, no. 4: 726-739.

Becker, G. S. 1964. Human Capital. A Theoretical and Empirical Analysis with Special Reference to Education. Chicago.

Becker, G. S. 1965. “A Theory of the Allocation of Time”. The Economic Journal 75, no. 299: 493-517.

Becker, G. S. 1973. “A Theory of Marriage: Part I”. Journal of Political Economy 81, no. 4: 813-846.

Becker, G. S. 1974. “A Theory of Marriage: Part II”. Journal of Political Economy 82, no. 2: 11-26.

Becker, G. S. 1976. The Economic Approach to Human Behavior. The University Chicago Press.

Becker, G. S. 1991. A Treatise on the Family. Harvard University Press.

Berg, N.; Lien, D. 2002. "Measuring the Effect of Sexual Orientation on Income: Evidence of Discrimination?" Contemporary Economic Policy 20, no. 4: 394-414.

Black, D. A.; Makar, H. R.; Sanders, S. G.; Taylor, L. J. 2003. "The Earnings Effects of Sexual Orientation”. Industrial \& Labor Relations Review 56, no. 3: 449-469.

Black, D. A.; Sanders, S.; Taylor, J. 2007. “The Economics of Lesbian and Gays Families”. Journal of Economic Perspectives 21, no. 2: 53-70. 
Blanford, J. M. 2003. "The Nexus of Sexual Orientation and Gender in the Determination of Earnings". Industrial \& Labor Relations Review 56, no. 4: 622-642.

Blau, F. D.; Kahn, L. M. 2007. “Changes in the Labor Supply of Married Women: 1980-2000”. Journal of Labor Economics 25, no. 3: 393-438.

Calandrino, M. 1999. Sexual Orientation Discrimination on the UK Labor Market. Working Paper St. Anthony's College, University of Oxford.

Caliendo, M.; Gehrsitz, M. 2014. Obesity and the Labor Market: A Fresh Look at the Weight Penalty. Center Discussion Paper 7.240.

Cameron, A. C.; Trivedi, P. K. 2005. Microeconometrics. Methods and Applications. Cambridge University Press.

Cameron, A. C.; Trivedi, P. K. 2009. Microeconometrics Using Stata. Stata Press.

Carpenter, C. S. 2005. "Self-Reported Sexual Orientation and Earnings: Evidence from California". Industrial \& Labor Relations Review 58, no. 2: 258-273.

Carpenter, C. S. 2007. "Revisiting the Income Penalty for Behaviorally Gay Men: Evidence from NHANES III". Labour Economics 14, no. 1: 25-34.

Carrilo, B.; Queiroz, P. W. V.; Charris, C. A.; Coelho, A. B. 2017. "New Evidence of the Effect of Body Weight on Labor Market Outcomes in a Developing Country". Pesquisa e Planejamento Econômico 47, no. 2: 177-196.

Casari, P.; Monsueto, S.; Duarte, P. 2013. "Impacto da orientação sexual sobre o rendimento do trabalho". In: ANAIS DO XLI ENCONTRO NACIONAL DE ECONOMIA, Foz do Iguaçu.

Case, A.; Paxson, C. 2006. Stature and Status: Height, Ability and Labor Market Outcomes. NBER Working Paper 12.466.

Castro Souza, J. R. 2013. "Produto potencial: onde estamos? Para onde vamos?” In: Giambiagi, F.; Porto, C. (org.). Propostas para o Governo 2015/2018. Agenda para um país próspero e competitivo. Rio de Janeiro: Campus.

Cawley, J. 2004. "The Impact of Obesity on Wages". Journal of Human Resources 39, no. 2: 451-474.

Cawley, J.; Burkhauser, R. V. 2006. Beyond BMI: The Value of More Accurate Measures of Fatness and Obesity in Social Science Research. NBER Working Paper 12.291.

Clain, S. H.; Leppel, K. 2001. "An Investigation into Sexual Orientation Discrimination as an Explanation for Wage Differences". Applied Economics 33, no. 1: 37-47.

Corrêa, M. V.; Irffi, G.; Suliano, D. 2012. "Existe diferencial entre casais heterossexuais e homossexuais? Uma abordagem para o mercado de trabalho brasileiro". In: ANAIS DO XL ENCONTRO NACIONAL DE ECONOMIA, Porto de Galinhas.

Cortes, G. M.; Jaimovich, N.; Siu, H. E. 2018. The "End of Men" and Rise of Women in the High-Skilled Labor Market. NBER Working Paper 24.274.

Curi, A. Z.; Menezes-Filho, N. A. 2008. "A relação entre altura, escolaridade, ocupação e salários no Brasil". Pesquisa e Planejamento Econômico, Rio de Janeiro, 38, no. 3: 413-458.

Currie, J.; Vogl, T. 2013. "Early-Life Health and Adult Circumstance in Developing Countries". Annual Review of Economics 5, no. 1, p. 1-36, 05.

Da Silva, W. R.; Dos Santos, D. D. 2016. "Trabalho e bem-estar: uma comparação entre casais heterossexuais e homoafetivos brasileiros". In: ANAIS DO XLIII ENCONTRO NACIONAL DE ECONOMIA, Foz do Iguaçu.

Davidowitz, S. S. 2018. Todo mundo mente. O que a internet e os dados dizem sobre quem realmente somos. Rio de Janeiro: ALTA BOOKS.

Deaton, A. 2017. A grande saída. Saúde, riqueza e as origens da desigualdade. Rio de Janeiro: Intrínseca.

Dilmaghani, M. 2017. "Sexual Orientation, Labour Earnings, and Household Income in Canada". Journal of Labor Research 39, no. 1: 41-55.

Ferguson, N. 2012. Civilização. Ocidente x Oriente. São Paulo: Planeta. 
Giambiagi F.; Muinhos, M. K. 2013. “A economia brasileira na segunda metade da década: riscos de esgotamento do ciclo de expansão iniciado em 2004”. In: Giambiagi, F.; Porto, C. (org.). Propostas para o Governo 2015/2018. Agenda para um país próspero e competitivo. Rio de Janeiro: Campus.

Giambiagi, F.; Schwartsman, A. 2014. Complacência. Entenda por que o Brasil cresce menos do que pode. Rio de Janeiro: Campus.

Giddings, L.; Nunley, J. M.; Schneebaum, A.; Zietz, J. 2014. "Birth Cohort and the Specialization Gap Between Same-Sex and Different-Sex Couples”. Demography 51: 509-534.

Gough, M.; Noonan, M. 2013. "A Review of the Motherhood Wage Penalty in the United States". Sociology Compass 7, no. 4: 328-342.

Gronau, R. 1977. "Leisure, Home Production, and Work - The Theory of the Allocation of Time Revisited". The Journal of Political Economy 85, no. 6: 1.099-1.123.

Hakim, C. 2012. Capital erótico. Pessoas atraentes são mais bem-sucedidas. A ciência garante. Rio de Janeiro: Best Business.

Harper, B. 2000. Beauty, Stature and The Labor Market: A British Cohort Study. Oxford Bulletin of Eonomics and Statistics.

Hayashi, F. 2000. Econometrics. Princeton University Press.

Heckman, J. J. 1979. “Sample Selection Bias as a Specification Error”. Econometrica 47 no. 1: 153-161.

Hoffmann, H.; Leone, E. T. A. 2004. "Participação da mulher no mercado de trabalho e desigualdade da renda domiciliar per capita no Brasil: 1981-2002". Nova Economia 14, no. 2: 35-58.

Hoffmann, H.; Simão, R. C. S. 2005. "Determinantes do rendimento das pessoas ocupadas em Minas Gerais em 2000: o limiar no efeito da escolaridade nas diferenças entre mesorregiões”. Nova Economia 15, no. 2: 35-62.

Humpert, S. 2016. "Somewhere Over the Rainbow: Sexual Orientation and Earnings in Germany". International Journal of Manpower 37, no. 1: 69-98.

Jacinto, P.; Frio, G.; Uhr, D.; Uhr, J. Z. 2017. "Offer of Work and Sexual Orientation: Evidence of Brazil”. The Empirical Economics Letters 16, no. 7: 663-667.

Jaspers, E.; Verbakel, E. 2014. "The Division of Paid Labor in Same-Sex Couple in the Netherlands". Sex Roles 68: $335-348$.

Jepsen, L. K. 1999. An Empirical Analysis of Same-Sex and Opposite-Sex Couples: Do 'Likes'Still Like 'Likes' in the '90s'? Northwestern University Institute for Policy Research Working Paper 99-5.

Kassouf, A. L. 1994. "The Wage Rate Estimation Using the Heckman Procedure”. Economia Aplicada 14, no. 1: 89-107.

Klawitter, M. M. 2015. "Meta-Analysis of the Effects of Sexual Orientation on Earnings". Industrial \& Labor Relations Review 54, no. 1: 4-32.

Klawitter, M. M.; Flatt, V. 1998. "The Effects of State and Local Antidiscrimination Policies on Earnings for Gays and Lesbians". Journal of Policy Analysis and Management 17, no. 4: 658-686.

Kubota, L. C. 2014. Discriminação contra os estudantes obesos e os muito magros nas escolas brasileiras. Rio de Janeiro: IPEA. (Texto para Discussão, 1.928).

Lafrance, A.; Warman, C.; Woolley, F. 2009. Sexual Identity and the Marriage Premium. Queen's Economics Department Working Paper 1.219.

Laurent, T.; Mihoubi, F. 2017. "Sexual Orientation, Unemployment and Participation: Are Gays Less Employable than Straights?" Journal Labor Research 38, no. 1: 1-44.

Leung, S. F.; Yu, S. 1996. "On the Choice Between Sample Selection and Two-Part Models”. Journal of Econometrics 72, no. 1-2: 197-229.

McLean, R. A.; Moon, M. 1980. "Health, Obesity and Earnings”. Public Health Briefs 70, no. 9: 1006-1009. 
Menezes-Filho, N. A. 2002. "Equações de rendimentos: questões metodológicas". In: Corseuil, C. H.; Fernandes, R.; Menezes-Filho, N. A.; Coelho, A. M.; dos Santos, D. D. (org.). Estrutura salarial. Aspectos conceituais e novos resultados para o Brasil. Rio de Janeiro: MTE, IPEA.

Mincer, J. 1974. Schooling, Experience and Earning. New York: Columbia University Press.

Oliveira, V. R.; Silveira, E.; Netto Balbinotto, G. 2017. Retornos salariais e problemas cardiovasculares: evidências para o caso brasileiro. In: ANAIS DO XLV ENCONTRO NACIONAL DE ECONOMIA, Natal.

Oreffice, S. 2007. "Did the Legalization of Abortion Increase Women's Household Bargaining Power? Evidence from Labor Supply". Review of Economics of the Household 5: 181-207.

Oreffice, S. 2011. "Sexual Orientation and Household Decision Making. Same-Sex Couples Balance of Power and Labor Supply Choices”. Labor Economics 18, no. 2: 145-158.

Oreffice, S.; Quintana-Domeque, C. 2016. "Beauty, Body Size and Wages: Evidence from a Unique Data Set". Economics \& Human Biology 22: 24-34.

Ozeren, E. 2014. "Sexual Orientation Discrimination in the Workplace: A Systematic Review of Literature". Procedia - Social and Behavioral Sciences 109: 1.023-1.215.

Ozturk, M. B. 2011. "Sexual Orientation Discrimination: Exploring the Experiences of Lesbian, Gay and Bisexual Employees in Turkey". Human Relations 64, no. 8: 1.099-1.118.

PESQUISA NACIONAL POR AMOSTRA DE DOMICÍLIOS CONTÍNUA. 2014a. Rio de Janeiro. IBGE. (Notas Metodológicas 1) $47 \mathrm{p}$.

PESQUISA NACIONAL DE SAÚDE. 2014b. "Percepção do Estado de Saúde, Estilos de Vida e Doenças Crônicas. Brasil, Grandes Regiões e Unidades da Federação". Rio de Janeiro. IBGE.

Petreski, M.; Blazevski, N. M.; Petreski, P. 2014. Gender Wage Gap When Women are Highly Inactive: Evidence from Repeated Imputations with Macedonian Data. MPRA Paper 57.226.

Plug, E.; Webbink, D.; Martin, R. N. 2014. "Sexual Orientation, Prejudice and Segregation". Journal of Labor Economics 32, no. 1: 123-159.

Ramos, C. A. 2015. Introdução à economia da educação. Rio de Janeiro: Alta Books.

Saboia, A. L.; Cobo, B.; Matos, G. G. 2012. Arranjos familiares e a metodologia para identificação de famílias no Censo 2010. Rio de Janeiro: IBGE. (Texto para Discussão, 39).

Schultz, T. 1960. "Capital Formation by Education”. Journal of Political Economy 68, no. 6: 571-583.

Schultz, P. 2005. Productive Benefits of Health: Evidence from Low Income Countries. Center Discussion Paper 903.

Suliano, D.; Irffi, G.; Barreto, A. B. 2019. "Orientação sexual e seus efeitos no mercado de trabalho: um estudo com base na técnica de revisão sistemática". In: ANAIS DO XVI ENCONTRO NACIONAL DA ABET, Salvador.

Suliano, D.; Irffi, G.; Corrêa, M. V. 2017. "Medidas antropométricas e retornos salariais com ênfase no padrão de atratividade e saúde corporal”. Pesquisa e Planejamento Econômico 47, no. 2: 197-230.

Suliano, D.; Irffi, G.; Corrêa, M. V.; Cavalcante, A. Oliveira, J. 2016. "Sexual Orientation and Wage Differentials in Brazilian Labour Market”. Economia Aplicada 20, no. 3: 195-221.

Tavares, P. A. 2010. "Efeito do programa Bolsa Família sobre a oferta de trabalho das mães". Economia e Sociedade 19, no. 3: 613-635.

Ueda, E. M.; Hoffmann, H. 2002. "Estimando o retorno da educação no Brasil". Economia Aplicada 6, no. 2: 209-238.

Wong, M. D.; Shapiro, M. F.; Boscardin, W. J.; Susan, L. E. 2002. “Contribution of Major Diseases to Disparities in Mortality". New England Journal of Medicine 347, no. 20: 1.585-1.592.

Zavodny, M. 2007. “Is There a ‘Marriage Premium’ for Gay Men?” IZA Discussion Paper 3.192. 


\section{Appendix A - Two Stage Heckman Model Selection Equations}

Table 6 - Two-Stage Heckman Model Selection Equations

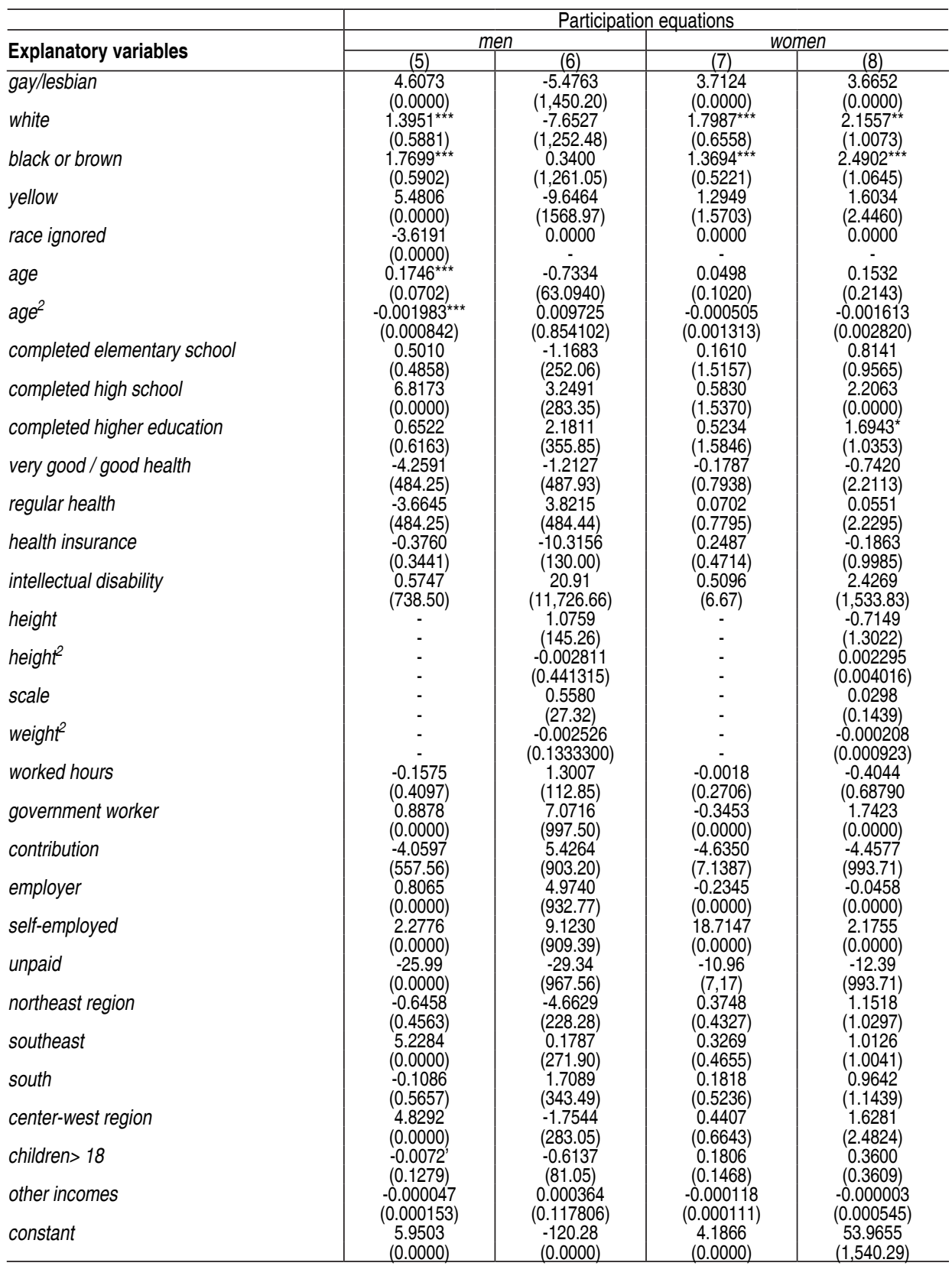

Source: Elaborated by the authors. Note: Robust standard errors in parentheses. ${ }^{* * *},{ }^{* *}$ and ${ }^{*}$ denote statistical significance at the $0.01,0.05$ and 0.1 levels. 